\title{
DIE BETEKENIS VAN PROF. BAVINCK SE VERBLYF IN S.A.
}

Noudat Prof. J. H. Bavinck weer terug is in sy vaderland is dit van belang om 'n oomblik stil te staan by die betekenis van sy verblyf van byna ' $n$ volle akademiese jaar in ons land. Onder baie moeilike omstandighede het prof. Bavinck hier aangekom, net na die dood van sy vrou wat vir hom in diens van die sending soveel beteken het. Met 'n sekere huiwering het hy sy dienste in Potchefstroom aanvaar, want hy bied sy dienste aan ' $n$ volk en land waar probleme is. Die vraag was of hy daarin sal slaag om van nut vir ons kerk en volk te wees. Maar nou agteraf gesien, beskou hy dit as 'n bestiering van die Here dat hy hierheen gekom het, en ons beskou sy koms hierheen as 'n gawe van God. Een ding het hy ons so duidelik geleer dat, as ons westerse beskawing nie in elke opsig deur die evangelie gedra word nie, dit ' $n$ vloek vir die heidenwêreld is. Ons kan die westerse beskawing nie maar klakkeloos aan die heidene oordra nie. Ons staan te weinig krities oor ons eie kultuurgoedere. Prof. Bavinck skrywe dan ook in verband met die sendingwerk: „In het algemeen genomen hebben de leiders van dat werk, hebben ook de zendingsarbeiders te weinig critisch gestaan tegenover hun eigen cultuurgoederen".

deur prof. P. J. S. DE KLERK.

Oor hierdie vraagstuk is daar gehandel op die internasionale sendingskonferensie van Tambaram in verband met die sendingsonderwys. Dit is noodsaaklik dat die hele onderwys dieper deurdronge moet wees van ' $n$ waaragtige christelike gees. Die christelike geloof moet die onderwys sodanig beheers dat dit heeltemal van karakter verander.

Prof. Bavinck is 'n man wat met altwee voete op die sendingsbodem staan. Die sending is vir hom geen bysaak nie, geen blote bevel van Christus nie, maar 'n saak van sy hele hart. Die liefde van Christus tot die verlorenes dring hom daartoe. Hy ken die nood van die heidenwêreld, maar ook die smart van die heidenhart. Hy het so telkens die nadruk daarop gelê dat die ontstamde naturel 'n leegte in sy lewe het wat alleen deur die evangelie van Jesus Christus gevul kan word. Maar dan moet Suid-Afrika ontwaak. Dis nog nie te laat nie, maar dan nou. Die Europese beskawing kan die naturel nie red nie.Christus moet aan hom 
gebring word. 'n Ontstamde naturel kan deur geen beskawing sonder dite Christelike godsdiens gered word me. Hy is 'n baie gevaarlike wese.

Met sy rondgaan in die verskillende gemeentes het hy byna elke Sondag die geleentheid gehad on op 'n boeiende en pakkende wyse die Evangelie te verkondig. Hy het deur middel van die radio sy boodskappe gevoelvol en met die gloed van oortuiging gebring, sodat vele daardeur gestig en opgebou is in die geloof. Hy het die geleenthede aangegryp om orals lesings te gee, hier in Potchefstroom, in Pretoria, in Johannesburg en in Stellenbosch. Die senaat van die Teol. Skool het hom uitgenooi, en alhoewel hy in diens van die scnaat was, was hulle maar al te gewillig om hom in die geleentheid te stel om in wyer kringe sy invloed te laat geld. Hy het 'n boodskap vir ons kerk en volk gehad, 'n boodskap wat in baie se harte weggesink het. Hy het ons nie alleen meer sendingbewus gemaak nie, maar hy het die sending nader aan ons harte gebring. Hy het op die groot sendingsprobleme gewys en in baie opsigte ons oë daarvoor geopen. Sy koms hierheen is van ontsettende groot betekenis vir ons rassevraagstuk. Hy het ons besiel om ons vraagstukke in die lig van Gods Woord op te los. Sy afskeidstoespraak, kort voor sy vertrek, getuig daarvan. Dit het diep ingeslaan, sodat almal oortuig was van ons groot verantwoordelikheid teenoor hulle wat die Here aan ons sorg toevertrou het. Niemand mag hier afsydig staan nie.

Ons beskou sy koms hierheen as 'n gawe van God. Een ding het hy ons so duidelik geleer dat, as ons westerse beskawing nie in elke opsig deur die evangelie gedra word nie, dit ' $n$ vloek vir die heidenwêreld is.

Elke Dinsdagaand het prof. Bavinck sy kolleges in sendingwetenskap in die kerkgebou gegee. Al die teologiese studente en al die studente wat hulle voorberei vir hulle teologiese studie, meer as tagtig, het die klasse bygewoon. Daar was ook elke keer heelwat besoekers. Daardie klasse was inspirerend. Die betekenis van prof. Bavinck se verblyf was ook hier van belang vir die Geref. kerk. Tot sover het drie studente hulle aangemeld om na voltooiing van hul studie na die sendingvelde uit te gaan. Vier het met goeie gevolg geslaag in die eksamen in sendingwetenskap. Ook die sendinggeskiedenis is gedeeltelik behandel. Daar was nie tyd om alles af te rond nie, want sommige periodes moes afgesonder word vir die Oosterse godsdienste. Van besondere belang was die lesings oor die pri- 
mitiewe godsdienste. Dis met die oog op ons naturelletoestand van aktuele belang. Dan het prof. Bavinck ook nog kolleges in pastoraalpsigiatrie gegee. Hierdie kolleges was van baie aktuele belang vir toekomstige predikante met die oog op huisbesoek. Prof. Bavinck is 'n fyn sielkundige. Sy kolleges in sielkunde aan die universiteit het groot belangstelling onder die studente gewek. Ook het hy weekliks kolleges in wysbegeerte gegee, wat van besondere belang was.

Woensdagmóres het alle kolleges stilgestaan gedurende die tweede periode, sodat al die studente van die universiteit en van die teologiese skool in die geleentheid gestel is om prof. Bavinck se lesings in geloofsleer by te woon. Die saal van die universiteit was dan ook altyd vol, want prof. Bavinck het hulle geboei $\mathrm{en}$ hierdie klasse was 'n besieling vir die studente.

Ons het nou 'n kort oorsig gegee van die omvangryke werk wat prof. Bavinck hier verrig het. Hy het dit met blydskap gedoen, terwyl sy gesondheid onder dit alles vooruitgegaan het. Met die saamtrek van Calviniste was dit ictwat vermoeiend. Daar het hy drie lesings gegee, en nog 'n lesing oor prediking voor die konferensie van predikante. Ook het hy nog die geleentheid gehad om voor die susters op te tree met 'n baie aktuele lesing oor die huwelik. In die verskillende afskeidswoorde het die betekenis van die verblyf van prof. Bavinck in ons midde dan ook baie duidelik uitgekom. Hy het een van ons geword en sy invloed sal nog lank gevoel word. Ons dank die Here dat Hy hom vir ons geleen het. Ons dank die kerkraad van Johannesburg-Noord, die Universiteit, die Senaat van die Teologiese Skool en veral die Vrije Universiteit en die Teologiesee Hoërskool in Kampen wat dit vir ons moontlik gemaak het. 